\author{
Haydar ASLANOV* \\ (Azerbaijan) \\ ANAS, Institute of Philosophy
}

\section{Limits of Integration into Modern World or Selfie with Anamorphosis}

\title{
Abstract
}

Over the past three decades, the new populated territories from the European peripheries, formerly secured from any dangers of distruction, fell under the influence of postmodernity. This has been accompanied by people's natural desire to take a chance to join the West that was a long-cherished dream for them. However, the intention to integrating into the modern world faces challenges posted by the same postmodern destructive processes. The very possibility to integrate is under question, since Lyotard declared the end of meta-narratives, and Baudrillard argued the authenticity of postmodern society. The overall image of the West, the Europe, emerged at times of Modernity, doesn't reflect the processes occurring in reality any more. All the basic concepts, which European meta-narrations were built upon the time of Modernity, are now mutilated beyond recognition. No longer are we able to recognize the Europe to integrate with, other than through our own implicit imagination. Just only because of its existence according to categories of modern we imagine the Europe has become available for free access now. These are the peripheries which, due to their archaic and traditional character, give meaning to the recent Europe. That is a reason the Europe, in turn, needs in us. We recreate the Europe having it on the pictorial background, while catching the image which only makes sense from our point of view. This constitutes the phenomenon of anamorphosis

*Phd, Azerbaijan National Academy of Sciences, heydar_01@hotmail.com. https://orcid.org/0000-0003-0129-2511. 
of nonexistence. Thus, the integration is just a posting of our presence to nonexistence, which we give importance to - the way we create the image while taking "selfie" with anamorphosis.

Keywords: postmodern, meta-narratives, integration, destruction, anamorphosis, Europe, selfie.

"You think you are photographing a scene for the pleasure of it, but in fact it is the scene that demands to be photographed, and you are merely part of the décor in the pictorial order it dictates"

J. Baudrillard ${ }^{1}$

\section{Charm of Presence}

Lately, post-modern has acquired new territories, which have not been participated it its genesis before. These territories, being exempted from any deformations and destructions in the past, now fell under the expansion of simulation of novelty. They have became concerned with the process of legitimating of their new status in pos-modern environment. These territories, along with their population, suddenly found themselves on stage of self-presentation, right after the "iron certain" raised. We are talking of geographic territories, former carriers of "mighty life programs", as Ortega y Gasset has expressed. ${ }^{2}$

At the same time, these new territories still retain their natural intention toward Lyotard's meta-narratives as the background for integration, while performing self-determination. A whish to integrate into "the World", the very same "nostalgia for meta-narratives" ${ }^{3}$ still exists within us. We strive for "civilized" standards of modern era, for standards at all, we still hope for mythology and sacredness of this world, hope for universal discourse (either humanistic, moral, cultural, national, edu-

\footnotetext{
${ }^{1}$ Бодрийяр, Ж. (2014). Прозрачность зла. (с. 225). Москва.: «КДУ».

2 Ортега-и-Гассет Хосэ. (2018). Восстание масс. (с.156). Москва.: АСТ.

3 Лиотар, Ж.-Ф. (1998). Состояние постмодерна. (с.100). Москва, СанктПетербург.: «Алатейя».
} 
Heydar Aslanov. Limits of Integration into Modern World or Selfie with Anamorphosis, s. 41-50

cational...). The intention toward self-determination and legitimization through communion with something great, if not yet politically arranged, is, after all, of our archetypical property.

However, how does the integration ever comply with post-modern environment? Does it make sense for us? Are we aliens to integrate to the world? Isn't our certified "exotics", which is shaped and adapted to perform for foreigners, an evidence of integration into mosaic world (say, world of tourism)? Isn't it a part of that global system of total consumerism, that same "entropic fatality of leveling all cultures", as expressed Baudrillard? ${ }^{1}$ After all, the very post-modern itself was determined by festivity of sovereignties of "little narratives", of values of "equal dialog" into which all have been integrated already. The very world has abandoned the "totalizing" and "suppressing" discourse of epic "grand narrative", leaving us with the unique great discourse of meta-consumerism. Under post-modern condition, any approved cultivation of "differences" - let them be of ethnic, cultural or technological just proves and backs the processes of destruction, deconstruction and disintegration. This cultivation gives the right to independence for differences, while their "integration" into disintegrating world is nothing more but merely evidence of affiliation to what exists no more. Disintegration sublates Participation, while allowing the Presence.

\section{Illusion or Anamorphosis?}

Behind the façade of radical and shocking self-presentation, the post-modern has hidden the "contemporary world", the "civilized world", or the "western world", mutilated beyond recognition. The "modern" and "advanced" no more equals to "progressive" and "humanistic". All these abstractions are nothing but well equalized to ensure comfort consumption - all which is framed by "the least marginal difference" 2 . The very metonymy of integrating objects looses its destination, as any metonymy with necessity leads to meta-narration. The very Human, as an aggregation of meta-narrations of civilization is thing of the past now. "The world no longer

\footnotetext{
${ }^{1}$ Бодрийяр, Ж. Прозрачность зла, р. 216

2 Бодрийяр, Ж. (2006). Общество потребления. Его мифы и структуры. (р. 117). Москва, «Культурная революция», «Республика».
} 
needs us", states Baudrillard. ${ }^{1}$ And this is not even a merely alienation, - this is dissolution of a human in operational pragmatism. The real power hides in the shade, leaving us with recycling whipping dolls of politicians. The power oppresses nobody anymore, it doesn't maintain the order by correcting marginal people - this appears as not of tolerant now. There is no more men, neither women around, hens no more need in heroes, as they violate political correctness. The indifference toward its own content has spread across the reality ${ }^{2}$, and resembles to absenteeism of images decorated on must-to-visit tourist's guides.

"The Clash of Civilizations" by Huntington ${ }^{3}$ lost its meaning completely, since meta-narrations were declared as devaluated. At the same time, it is naïve to rely on unipolar world as well. All attempts of the States to govern the world just evoke even more reasons the world is to be governed for. The policeman just induces incidents, which presumably is to solve later on. Meantime, world nations do not consider America as traditional governor for one simple reason: the very same America has emerged while being on the great run, the escape from world nations. Even if, as Huntington insists, to call this escape as happened "to seek a better future". ${ }^{4}$ Whatever we want to call it, it still won't add any legitimacy to unipolar governor- the very same legitimacy Lyotard was concerned of ${ }^{5}$. Eventually, it is hard to disagree with the fact, that loosing proper relations of "power and subordination" distorts the reality badly. ${ }^{6}$ Nowadays, only Europe remains connoted with "the world". But that connotation is all that's left of the Europe.

This transformation constitutes the post-modern anamorphosis of the "contemporary world", the world, that will never be the same West - but only from the point of view of its provinces. Deconstruction of meta-narratives leaves nothing for

1 Бодрийяр, Ж. «Почему все еще не исчезло?», www.chaskor.ru/article/ zhan_bodrijyar_pochemu_vse_eshche_ne_ischezlo_40860 (Accessed on March 28, 2019)

${ }^{2}$ Бодрийяр, Ж. (2014). Прозрачность зла.( с.12а.). Москва «КДУ».

${ }^{3}$ Хантингтон, С. (2003). Столкновение циивилизаций. Москва.: «АСТ».

4 Хантингтон С. (2008). Kmo мыз Bblзовы американской национальной идентичности. (р.77) Москва.: «АСТ».

5 Лиотар Жан-Франсуа. (1998). Состояние постмодерна. Москва, СанктПетербург,.: «Алтейя».

${ }^{6}$ Ортега-и-Гассет Хосэ. (2018). Восстание масс. (с.152). Москва.: Издательство ACT. 
Heydar Aslanov. Limits of Integration into Modern World or Selfie with Anamorphosis, s. 41-50

great metonymies. The West is doomed to exist within the perception of its peripheries, among which it still refers to the use-value, while continuously slipping over the horizon of veracity - doomed to exist as anamorphosis, which recognition and legitimacy depends on spectators' attitude.

By that, not the world itself, but its anamorphosis is in need of us now, is in need of interested spectators - the same way the "concept art" is in need of people from the street to resettle itself into their self-conceit minds for proliferation. The same way "unconscious God" of Lacan ${ }^{1}$ resettles onto cozy background of family quotes of welfare. The same way the Buddhist robot priest doles out advice in Japanese Buddhist temple ${ }^{2}$, performing micro-narrative performance about integration of already destroyed temple into the "contemporary world". The West has no more chances for sovereign being - it is dismantling now. But nevertheless, the barbarians still save Rome.

\section{Have We ever Landed the Europe?}

The "New human type", the "Mass-man", declaring own mediocrity and claming the right for $\mathrm{it}^{3}$ - that is who strives to integrate its traditional territories into Europe. This is another abduction of Europe by the bulls from peripheries. Paris is in hands, hence we are Europeans now. Mass-man enjoys the access to something once forbidden, but now available, since destroyed. Now everyone can penetrate the site through the shattered walls, walk over the ruins of temples, take pictures of "holy of holies"... The ruins are indifferent, according to post-modern rules. They even belong to humankind any longer. As a result, we all appropriate the Europe, we inherit her, and as seems to us, we acquire legitimacy by that.

That is not even a communion, though. Communion is an assumption of that gone through cannibalistic action - eating the body of Europe in our case - that is, obtaining the spirit of the late, inheriting its sacred power. But since there is no

\footnotetext{
${ }^{1}$ Лакан, Ж. ( 2004). Четыре основных понятия психоанализа. (с. 67) Семинары: Книга 11(1964). Москва.: «Гнозис», «Логос».

${ }^{2}$ Ryall, J. Buddhist robot priest to dole out advice in Kyoto temple. «The Telegraph», 25 Feb. 2019// www.telegraph.co.uk/news/2019/02/25/buddhist -robot-priest-dole-advicekyoto-temple; (Accessed on March 28, 2019)

${ }^{3}$ Ортега-и-Гассет Хосэ. Восстание масс, (c.145).
} 
body, nor is there any sacredness, then there is nothing to communion by. Nothing on hands left, but anamorphosis, which we only able to cognize. Simulation of communion is only available for us, which is just merely fixation of presence proving affiliation - that is selfie. Only selfie gives meaning to any distorted post-modern anamorphosis.

Should we leave Europe alone, where it stands, as a distant hence more needed stimulus for spiritual growth? The way the very same Zeus temple is? Moreover, don't we have our own respective images, our own temples to maintain spiritual level? We have them now as distant as European ones, to be as desired. But still what indeed leads us in our hike for Europe? Eventually, there is no more need for spiritual growth, since it gives no profit, and the knowledge no more shapes the person (Lyotard again) ${ }^{1}$. After all, there is no more Europe nor Zeus, and very same appellative France, paradoxical it may sound, stands farthest from European ideals, as "the first country, which broke up with European tradition"2.

There is still specific meaning of selfie with non-existed, a kind of intrigue of easy creation of irreversible authenticity. Selfie refers to its epic historical prototype (apparently, to determine the source of obsession, one needs to find its initial epic provocation) - that is selfie made by man with the Earth while stepping on the Moon. Since that time, the very act of selfie has been inextricably linked to verification. Selfie is not only an act of verification of depicted object, but also turns to an act of determination of its own credibility. With availability of digital editing, we feel concerned not as much by verification of our presence on site, as by credibility of the pictured itself. And we prove that credibility by framing ourselves along with the object. The traces of conspiracy still exist, whether we like it or not, as that very same shadow wrongly cast on the Moon. That is why, only the metaphor of "selfie" is to be used to reflect the availability of integration into questionable anything.

So, the fake of contemporary world calls us to confirm its authenticity, its anamorphosis calls us to restore the reality. It is Europe now who abducts bulls for use, to get her beauty back again. The more we're culturally creditable, the more

\footnotetext{
1 Лиотар Жан-Франсуа. Состояние постмодерна, с.18

2 Венер Доменек. (2018). История и традициия европейщев. 30000 лет идентичности. (р.195) Москва.: «Тотенбург».
} 
Heydar Aslanov. Limits of Integration into Modern World or Selfie with Anamorphosis, s. 41-50

we're of archaic, traditional and peripheral, the more we are of "Oquz" if you like, - the stronger that anamorphosis of the Europe needs us. And since the Europe persists in seduction, it is precisely because of knowing the secret (the same secret the Power, by Baudtillard, knows about itself ${ }^{2}$ ) that it exists no more.

We give a meaning to integration while simply capturing our own image in front of anamorphosic background. We stand in front of desired value, which is deprived from equivalency, and by taking "selfie" with that mirage we create some hope for the West, as well for ourselves. Having our archaic romanticism of peripheries, we are rescuing the West - through the remains of formerly effective but nowadays infamous meta-narrations. Because we are still under the influence of communion, under the illusion of self-superiority over the immanent reality, under the illusion of restored ties with metaphysics, with meta-narrations of heritage, with heroic past, - we are still under the illusion of reunion with that, where the Sun leads us with nonexistent, hence unreachable horizon in the west.

We have turned out to be more of Europeans, (having our residual education, our discourse of public justice, with our smart phones on hands), than distorted and destructed autochthons of Europe. At the same time, we remained to seem like Baudrillard's simulacra of integration, which have no any reference, since the West no more exists. That is the same "Value's Last Tango"3. Rephrasing, we can say: "Value's Last Selfie". What happens next is unknown. By now it is clear, however, that by integrating we have nothing to loose but the revealed anamorphosis.

\section{References:}

1. Bodriyyar, J. (2000). Zabit Fuko. (Per. S fr. Kaluqin, D.). Sankt-Peterburq: Vladimir Dal.

2. Bodriyyar, J. (2006). Obshestvo potrebleniya. Eqo mifi I strukturi. (Per. s fr. Samarskoy, E.). Moskva: Kulturnaya revolyutsiya, Respublika.

3. Bodriyyar, J. Pochemu vse eshe ne ischezlo? (Per. s fr. Bolqova, A.)// www.chaskor.ru/article/ zhan_bodrijyar_pochemu_vse_eshche_ne_ischezlo_40860, (Accessed on March 28, 2019).

1 "Oquz" - an ancient Turkic tribe, ancestor of Azeris, named after its totem - "the Bull”.

${ }^{2}$ Бодрийяр, Ж. (2015). Забыть Фуко, (р.85). Санкт-Петербург.: «Владимир Даль».

${ }^{3}$ Бодрийяр, Ж. Симулякры и симуляции (с.203). Москва.: «ПОСТУМ». 
4. Bodriyyar, J. (2014). Prozrachnost zla. (Per. s fr. Lyubarskoy, L. \& Markovskoy, E.). Moskva: Izdatelstvo KDU.

5. Bodriyyar, J. (2015). Simulyakri i simulyatsii. (Per. s fr. Kachalova, A.). Moskva: POSTUM.

6. Vener, D. (2018). Istoriya I traditsiya evropeytsev. 30000 let identichnosti. Moskva: Totenburq.

7. Lakan, J. (2004). Chetire ocnovnix ponyatiya psixoanaliza. Seminari: Kniqa 11(1964). (Per. s fr. Chernoqlazova, A.). Moskva: Qnozis, Loqos.

8. Liotar, J.F. (1998). Sostoyanie postmoderna. (Per. s fr. Shmatko, N.A.). Moskva, Sankt-Peterburq: Alteyya.

9. Orteqa-i-Qasset, X. (2018). (Per. s isp. Qeleskula, F.). Vosstanie mass. Moskva: Izdatelstvo AST.

10. Hantinqton, S. (2008). Kto mi? Vizovi amerikanskoy natsionalnoy identichnosti. (Per. s anql. Bashkirova, F.). Moskva: AST.

11. Hantinqton, S. (2003). Stolknovenie tsivilizatsiy. (Per. s anql. Novikova, Y.). Moskva: AST.

12. Ryall, J. Buddhist robot priest to dole out advice in Kyoto temple.// The Telegraph, 25 Feb. 2019// www.telegraph.co.uk/news/2019/02/25/buddhist -robotpriest-dole-advice-kyoto-temple; (Accessed on March 28, 2019)

\section{Dr. Heydor Aslanov}

\section{Postmodern dövründo inteqrasiya hüdudları, yaxud anamorfozla selfi}

(xülasə)

Son üç onillik arzinda Avropanın periferiyasında yerlaşən, müxtalif xalqların maskun olduqları, avvallar destruktiv proseslarin toxunmadığ yeni arazilar postmodernin tasirina maruz qalmışdır. Bu fenomen, insanlarda onların asrlar boyu idealı olan Qərbla qovuşmaq imkanından istifadə etmək arzusu doğurdu. Buna rəğmən, müasir dünyaya inteqrasiya etmak arzusu həmin destruktiv mahiyyatli postmodern proseslarinin çağırışları ila rastlaşır. Liotarın metanarrativlarin sona çatdlğını elan etdiyi, Bodriyarın isa indiki dünya hadisalarinin mötabarliliyina şübha yaratdiğg dövrdən etibarən inteqrasiyanın mümkünlüyü sual altındadır. Bütövlükdə Qərbin, xüsusən də Avropanın modern dövründə formalaşmış surəti gerçəklikdə baş verən proseslari artıq aks etdirmir. Modern dövrünün Avropa metanarrativlarinin onlartn üzarinda qurulmuş olduğu bütün asas tasisatlar indi tanınmaz daracada destruksiyaya va ya deformasiyaya uğrayıb. Biz artıq Avropanın tomsil etdiyi dünyanı arzuolunan inteqrasiya obyekti kimi təxəyyülümüzdən başqa heç bir şeydə tapa bilmirik. 
Heydar Aslanov. Limits of Integration into Modern World or

Selfie with Anamorphosis, s. 41-50

Avropa artıq onu modern kateqoriyalarında tasovvür etdiyimiz kimi deyil va yalnız buna göra bizim üçün alçatan olub. Belalikla, öz arxaikliyi va onənəviliyi sabəbindan takco periferiya bugünkü Avropaya mona verə bilar. Buna göro da Avropanın özü bizə möhtacdır. Biz Avropanı özümüzü onun fonunda yerlaşdirarək canlandırlrıq, yalnız bizim nöqteyi-nəzərimizdon mövcud olanı tasbit edirik. Məhz bu, mövcud olmayanın anamorfozasını toşkil edir. Belaliklo, inteqrasiya bizim mövcud olmayan və anamorfoza ila selfi edərkən surət yaratdığımız zaman olduğu kimi, bizim məna verdiyimiz xəyali varlıqda yalnız iştirakımızdır.

Açar sözlar: postmodern, metanarrativlar, inteqrasiya, müasir dünya, destruktiv, anamorfoza, Avropa, selfi, iştiraketmo, mötabarlik.

\section{Др. Гейдар Асланов}

\section{Пределы интеграции в эпоху постмодерна, или селфи с анаморфозой \\ (резюме)}

За последние три десятка лет под влияние постмодерна стали подпадать новые населенные территории с периферии Европь, прежде не затронутые проиессами деструкции. Это сопровождалось естественным желанием людей воспользоваться возможностью приобщения к давнему идеалу, каким являлся для них Запад. Однако желание интегрироваться в современный мир наталкивается на вызовы со стороны тех же деструктивных прочессов постмодерна. С тех пор, как Лиотар объявил о конще метанарративов, а Бодрийяр оспорил достоверность явлений современного мира, сама возможность интеграции находиться под вопросом. Образ Запада, в иелом, особенно, Европьл, сформированный в эпоху модерна, больше не отражает процессов, происходящчх в действительности. Все основные институты, на которых строились европейские метанарративь эпохи модерна, теперь деструктурировань или деформированы до неузнаваемости. Мы уже не можем ни в чем обнаружить мир в образе Европь, как желанный объект интеграции, разве что в нашем воображении. Европа стала доступной для нас, но лишь потому, что мы все еще представляем ее в категориях модерна. Таким образом, только периферия, в силу своей архаичности и традиционности, способна вновь придать смысл сегодняшней Европе. По этой причине, Европа сама нуждается в нас. Mbl воссоздаем Европу помещзая себя на ее фоне, фиксируем то, что существует только с нашей точки зрения. Это и составляет анаморфозу несуществующего. Интеграџия, таким образом, есть лишь наше присутствие в несуществуюшем, которому мы лишь придаем смысл - так же как мы создаем образ, делая селфи с анаморфозой. 
Ключевые слова: постмодерн, метанарративы, интеграиия, деструкчия, анаморфоза, Европа, селфи.

Maqala redaksiyaya daxil olmuşdur: 10.04.2019 Təkrar işləməyə göndərilmişdir: 21.04.2019

Çapa qabul edilmişdir: 06.05 .2019 